\title{
Bioactive compounds (phytoestrogens) recovery from Larrea tridentata leaves by solvents extraction
}

\author{
Silvia Martins ${ }^{\mathrm{a}}$, Cristóbal N. Aguilar ${ }^{\mathrm{b}}$, José A. Teixeira ${ }^{\mathrm{a}}$, Solange I. Mussatto ${ }^{\mathrm{a}, *}$ \\ a Institute for Biotechnology and Bioengineering (IBB), Centre of Biological Engineering, University of Minho, Campus Gualtar, 4710-057 Braga, Portugal \\ ${ }^{\mathrm{b}}$ Food Research Department, School of Chemistry, Autonomous University of Coahuila, Blvd. Venustiano Carranza S/N Col. República Oriente, 25280 Saltillo, Coahuila, Mexico
}

\section{A R T I C L E I N F O}

\section{Article history:}

Received 2 November 2011

Received in revised form 3 December 2011

Accepted 16 December 2011

Available online 24 December 2011

\section{Keywords:}

Antioxidant capacity

Kaempferol

Larrea tridentata

Nordihydroguaiaretic acid

Quercetin

\begin{abstract}
A B S T R A C T
Methanol, ethanol, and acetone at four different concentrations $(90 \%, 70 \%, 50 \%$, and $30 \% \mathrm{v} / \mathrm{v})$ were used for extraction of phytoestrogens (nordihydroguaiaretic acid (NDGA), kaempferol, and quercetin) from Larrea tridentata leaves. Besides the phytoestrogens extraction, the antioxidant potential, and the contents of total phenols, flavonoids, and protein in the produced extracts were also determined. The solvent and concentration used for extraction strongly affected the phytoestrogens recovery. The highest NDGA, quercetin, and kaempferol contents $(46.96 \pm 3.39,10.46 \pm 1.01$, and $87.00 \pm 6.43 \mathrm{mg} / \mathrm{g}$ DW plant, respectively) were recovered using $90 \%(\mathrm{v} / \mathrm{v})$ methanol. All the produced extracts showed antioxidant capacity, but those obtained using $70 \%$ and $90 \%(v / v)$ methanol had significantly higher $(p<0.05)$ FRAP (ferric reducing antioxidant power) values $(2.55 \pm 0.09$ and $2.73 \pm 0.11 \mathrm{mM} \mathrm{FE}(\mathrm{II}) / \mathrm{g} \mathrm{DW}$ plant, respectively) than the remaining ones. Extract produced by using $90 \%(\mathrm{v} / \mathrm{v})$ methanol contained also the highest contents of total flavonoids (19.29 $\pm 0.79 \mathrm{mg} \mathrm{QE} / \mathrm{g} \mathrm{DW}$ plant) and protein $(131.84 \pm 6.23 \mathrm{mg} / \mathrm{g}$ DW plant), and elevated total phenols concentration $(263.60 \pm 25.78 \mathrm{mg} \mathrm{GAE} / \mathrm{g}$ DW plant).
\end{abstract}

(c) 2011 Elsevier B.V. All rights reserved.

\section{Introduction}

Phytoestrogens including flavonoids (comprising isoflavonoids and flavonols derivatives), lignans, and coumestanes, are secondary plant metabolites that have attracted great attention due to their protective action against several health disorders such as cardiovascular diseases, cancer, brain function disorders, menopausal symptoms, and osteoporosis [1]. Such compounds have the ability to imitate or modulate the effectiveness of endogenous estrogens. This biological response is based on their structural and/ or functional similarity to estradiol and their capacity to bind to the human estrogen receptors (ER). Some studies have shown that selective ER modulators, including phytoestrogens, inhibit cell proliferation in vitro [2] and in vivo [3].

Larrea tridentata (Zygophyllaceae), commonly known as creosote bush, is a plant that grows in semidesert areas of Southwestern United States and Northern Mexico [4]. This plant was traditionally used for centuries by North American Indians as a medicine for several illnesses including infections, kidney problems, gallstones, rheumatism and arthritis, diabetes, and to treat tumors [5]. L. tridentata is an outstanding source of natural compounds with approximately $50 \%$ of the leaves (dry weight) being extractable

\footnotetext{
* Corresponding author. Tel.: +351 253604 424; fax: +351253604 429.

E-mail addresses: solange@deb.uminho.pt, solangemussatto@hotmail.com (S.I. Mussatto).
}

matter [6]. Among several bioactive compounds present in this plant, nordihydroguaiaretic acid (NDGA), kaempferol, and quercetin can be found at considerable high concentrations [7].

NDGA (Fig. 1A) is a phenolic lignan with biological activities of large interest in the health area, such as antiviral, antifungic, antimicrobial, and antitumorgenic [8]. The therapeutic potential of this compound for the treatment of tumors and cancer has been demonstrated, being related to an inhibition on cancer cells growth via an apoptotic mechanism [9]. Kaempferol and quercetin are flavonols that exist as a variety of glycosides or in aglycone form. The aglycone forms of kaempferol and quercetin are structurally similar, differing only by one hydroxyl group in the B-ring (Fig. 1B and C). Research on cell culture models has shown important biochemical effects of both compounds, which are relevant to carcinogenesis, including increase of differentiation and gap junction function [10], metal chelation [11], antioxidant properties [12], the inhibition of hepatic enzymes involved in carcinogen activation [13], the induction of Phase II (conjugating) enzymes [14], and the influence of ER-transcriptional activity of ERE-reporter systems [15]. Despite the anticarcinogenic capacity of kaempferol and quercetin, these compounds are also known for their anti-inflammatory and antinociceptive capacities [16].

Nowadays, bioactive compounds with potential health benefits have attracted great interest for use in several industrial areas, and researches on this topic have been strongly encouraged. Extraction is the first step in the isolation of compounds from natural sources. 
(A)<smiles>CC(Cc1ccc(O)c(O)c1)C(C)Cc1ccc(O)c(O)c1</smiles>

(B)<smiles>O=c1c(O)c(-c2ccc(O)cc2)oc2cc(O)cc(O)c12</smiles>

(C)<smiles>O=c1c(O)c(-c2ccc(O)c(O)c2)oc2cc(O)cc(O)c12</smiles>

Fig. 1. Chemical structure of NDGA (A), kaempferol (B), and quercetin (C).

Among the variety of techniques that can be used for this purpose, solid-liquid extraction has been widely employed to extract bioactive compounds from plant materials and agro-industrial residues [17]. However, the efficiency of this extraction process is greatly affected by the type of solvent and its concentration $[17,18]$, and therefore, studies to define the best conditions for these variables are necessary to maximize the extraction yields to each different plant material. Despite several studies evaluating the best solvents to extract the maximum content of phenolic compounds from plant matrices and the antioxidant potential of the produced extracts are reported in the literature, to the best of our knowledge, no detailed study has been developed with $L$. tridentata. Thus, the purpose of this study was to evaluate the effect of different organic solvents on the extraction of phytoestrogens, in particular, NDGA, kaempferol, and quercetin, from $L$. tridentata leaves. The antioxidant potential of the produced extracts, as well as the contents of total phenols, flavonoids, and proteins were also determined and are discussed.

\section{Materials and methods}

\subsection{Plant material and chemicals}

Plant material (L. tridentata) was collected from the Chihuahuan semidesert (North Coahuila, Mexico) during Spring season (April, 2009). Nordihydroguaiaretic acid (NDGA), 1,1-diphenyl-2picrylhydrazyl (DPPH), quercetin, kaempferol, aluminum chloride, 2,4,6-tris (1-pyridyl)-5-triazine (TPTZ), sodium acetate, ferrous sulfate, and iron (III) chloride were purchased from Sigma-Aldrich (Saint Louis, MO, USA). Reagent-grade methanol, ethanol, acetone, acetic acid, and Folin-Ciocalteau were from Panreac (Barcelona, Spain). Potassium acetate was purchased from AppliChem (Darmstadt, Germany). HPLC-grade acetonitrile was obtained from Fisher Scientific (Leicestershire, UK). Ultrapure water from a Milli-Q System (Millipore Inc., USA) was used.

\subsection{Extraction methodology}

Air-dried leaves of $L$. tridentata were ground to fine powder and stored in dark bottles at room temperature for further use.
Extractions were performed by mixing $1 \mathrm{~g}$ of plant material with $20 \mathrm{ml}$ of organic solvent (methanol, ethanol or acetone, in a concentration of $90 \%, 70 \%, 50 \%$, or $30 \% \mathrm{v} / \mathrm{v}$ ) or distilled water. The mixtures were heated during $30 \mathrm{~min}$ in a water-bath at $70^{\circ} \mathrm{C}$ when using methanol, ethanol, or water, and at $60^{\circ} \mathrm{C}$ when using acetone, due to its lower boiling point. After this time, the produced extracts were filtered through qualitative filter paper and stored at $-20^{\circ} \mathrm{C}$ until further analysis.

\subsection{Bioactive compounds quantification}

NDGA, kaempferol, and quercetin concentrations were determined by high performance liquid chromatography (HPLC) on an equipment LC-10 A (Jasco, Japan) with a $\mathrm{C}_{18} 5 \mu \mathrm{m}(3.9 \times 300 \mathrm{~mm})$ column at room temperature, and a UV detector at $280 \mathrm{~nm}$. The response of the detector was recorded and integrated using the Star Chromatography Workstation software (Varian). The mobile phase consisted of acetonitrile (solvent $\mathrm{A}$ ) and $0.3 \%$ acetic acid in water ( $\mathrm{v} /$ v) (solvent $B$ ) under the following gradient profile: $30 \% \mathrm{~A} / 70 \% \mathrm{~B}$ (0-2 min), 50\% A/50\% B (2-11 min), 70\% A/30\% B (11-17 min), $100 \% \mathrm{~A}(17-22 \mathrm{~min})$, and $30 \% \mathrm{~A} / 70 \% \mathrm{~B}(22-40 \mathrm{~min})$. The mobile phase was eluted in a flow rate of $1.0 \mathrm{ml} / \mathrm{min}$, and samples of $10 \mu \mathrm{l}$ were injected. Previous the analysis, all the extracts were filtered through $0.2 \mu \mathrm{m}$ membrane filters. NDGA, kaempferol, and quercetin were expressed as the ratio between mass of the compound in the extracts and mass of plant material (dry weight).

\subsection{Determination of total phenols content}

Total phenols content was determined by the Folin-Ciocalteu method with modifications. Briefly, $5 \mu$ l of the filtered extracts duly diluted were mixed with $60 \mu$ of sodium carbonate solution (7.5\% w/v) and $15 \mu \mathrm{l}$ of Folin-Ciocalteu reagent in a 96-well microplate. Then $200 \mu \mathrm{l}$ of distilled water were added and solutions were mixed. After standing for $5 \mathrm{~min}$ at $60^{\circ} \mathrm{C}$ samples were allowed to cool down at room temperature. The absorbance was measured using a spectrophotometric microplate reader (Sunrise Tecan, Grödig, Austria) set at $700 \mathrm{~nm}$. A calibration curve was prepared using a standard solution of gallic acid (200, 400, 600, 800, 1000, $\left.2000,3000 \mathrm{mg} / \mathrm{l}, r^{2}=0.9987\right)$. The total phenols content determined according to the Folin-Ciocalteau method are not absolute measurements of the phenolic compounds amounts, but are in fact based on their chemical reducing capacity relative to an equivalent reducing capacity of gallic acid. Thus, total phenols content was expressed as milligram gallic acid equivalent (mg GAE)/g DW plant material (dry weight).

\subsection{Determination of total flavonoids content}

Total flavonoids content was quantified by colorimetric assay. Briefly, $30 \mu \mathrm{l}$ of the diluted and filtered extracts was added to $90 \mu \mathrm{l}$ of methanol in a 96-well microplate. Subsequently, $6 \mu \mathrm{l}$ of aluminum chloride $(10 \% \mathrm{w} / \mathrm{v}), 6 \mu$ of potassium acetate $(1 \mathrm{~mol} / \mathrm{l})$ and $170 \mu \mathrm{l}$ of distilled water were added to the mixture. The absorbance of the mixture was measured after $30 \mathrm{~min}$ at $415 \mathrm{~nm}$ against a blank prepared with distilled water, using a spectrophotometric microplate reader (Sunrise Tecan, Grödig, Austria). A calibration curve was prepared using a standard solution of quercetin (25, $\left.50,100,150,200 \mathrm{mg} / \mathrm{l}, r^{2}=0.9994\right)$. Total flavonoids content was expressed as milligram quercetin equivalent ( $\mathrm{mg}$ of $\mathrm{QE}$ )/gDW plant material (dry weight).

\subsection{Determination of protein content}

Total protein content was estimated using the Bradford assay. 


\subsection{Free radical scavenging activity}

The free radical activity of $L$. tridentata extracts was determined by measuring the ability of the extracts to scavenge the free radical 1,1-diphenyl-2-picrylhydrazyl (DPPH). The DPPH radical scavenging activity was determined according to Hidalgo et al. [19] with modifications. Ten microliters of each extract, duly diluted in methanol, was added to $290 \mu \mathrm{l}$ of DPPH solution $\left(6 \times 10^{-5} \mathrm{M}\right.$ in methanol and diluted to an absorbance of 0.700 at $517 \mathrm{~nm}$ ) in a 96-well microplate. The resulting solutions were vortexed, and allowed to stand for $30 \mathrm{~min}$ in darkness at room temperature. Then the absorbance was measured at $517 \mathrm{~nm}$ in a spectrophotometric microplate reader (Sunrise Tecan, Grödig, Austria), using methanol as blank. The control solution consisted in using methanol instead of the sample. The radical scavenging activity was expressed as the inhibition percentage using the following equation:

$\%$ inhibition of $\mathrm{DPPH}=\left(1-A_{S} / A_{C}\right) \times 100$

where $A_{C}$ and $A_{S}$ are the absorbance of the control solution and the absorbance of the sample solutions, respectively.

\subsection{Ferric reducing/antioxidant power assay (FRAP assay)}

Briefly, $10 \mu \mathrm{l}$ of duly diluted and filtered extract was mixed with $290 \mathrm{ml}$ of FRAP reagent in a 96-well microplate. Then, the reaction mixture was incubated at $37{ }^{\circ} \mathrm{C}$ for $15 \mathrm{~min}$. After that, the absorbance was determined at $593 \mathrm{~nm}$ against a blank prepared using distilled water. FRAP reagent should always be freshly prepared by mixing a $10 \mathrm{mM} \mathrm{2,4,6-tris} \mathrm{(1-pyridyl)-5-triazine} \mathrm{(TPTZ)} \mathrm{solution}$ in $40 \mathrm{mM} \mathrm{HCl}$ with a $20 \mathrm{mM} \mathrm{FeCl}_{3}$ solution and $0.3 \mathrm{M}$ acetate buffer $(\mathrm{pH}$ 3.6) in a proportion $1: 1: 10(\mathrm{v} / \mathrm{v} / \mathrm{v})$. A calibration curve was prepared using an aqueous solution of $\mathrm{FeSO}_{4} \cdot 7 \mathrm{H}_{2} \mathrm{O}(200,400,600$, 800 , and $1000 \mu \mathrm{M}, r^{2}=0.9992$ ). FRAP values were expressed as millimoles of ferrous equivalent ( $\mathrm{mM} \mathrm{Fe}$ (II))/g DW plant material (dry weight).

\subsection{Statistical analysis}

All the experimental conditions and determinations were performed in triplicate, and mean values \pm standard errors are presented. Results were analyzed by one-way analysis of variance (ANOVA) using the general linear model of SPSS (Statistical Package for Social Sciences, version 16.0) for a significance level of $p<0.05$. Difference among samples was verified by using the Tukey's range test. Linear regression analysis was performed quoting the correlation coefficient $r_{x y}$.

\section{Results and discussion}

\subsection{Effect of organic solvents on the extraction of phytoestrogens}

NDGA, kaempferol, and quercetin extraction from $L$. tridentata leaves varied considerably according to the used solvent (Table 1), probably due to the polarity of each solvent and the solubility of the compounds in them [20]. Low concentration levels of all the three phytoestrogens were observed on the aqueous extracts, which can be explained by their low solubility in water [21]. The highest NDGA, kaempferol, and quercetin contents (46.96 \pm 3.39 , $87.00 \pm 6.43$ and $10.46 \pm 1.01 \mathrm{mg} / \mathrm{g}$ dry wt plant, respectively) were recovered using $90 \%(\mathrm{v} / \mathrm{v})$ methanol as extraction solvent. These results are in agreement with those obtained by Lin and Giusti [22] who reported that extracting solvents with higher polarity extracted a significantly higher amount of bioactive compounds (isoflavones) from soybeans. In the present study, the highest
Table 1

Phytoestrogens extraction from Larrea tridentata leaves using different organic solvents.

\begin{tabular}{lccc}
\hline $\begin{array}{l}\text { Solvent } \\
(\% \mathrm{v} / \mathrm{v})\end{array}$ & $\begin{array}{l}\text { NDGA }(\mathrm{mg} / \mathrm{g} \text { dry } \\
\text { wt plant })\end{array}$ & $\begin{array}{l}\text { Kaempferol }(\mathrm{mg} / \mathrm{g} \\
\text { dry wt plant) }\end{array}$ & $\begin{array}{l}\text { Quercetin }(\mathrm{mg} / \mathrm{g} \text { dry } \\
\text { wt plant) }\end{array}$ \\
\hline $\mathrm{H}_{2} \mathrm{O}$ & $2.12 \pm 0.25^{\mathrm{h}}$ & $8.00 \pm 0.94^{\mathrm{e}}$ & $2.28 \pm 0.17^{\mathrm{f}}$ \\
Methanol & & & \\
90 & $46.96 \pm 3.39^{\mathrm{a}}$ & $87.00 \pm 6.43^{\mathrm{a}}$ & $10.46 \pm 1.01^{\mathrm{a}}$ \\
70 & $33.57 \pm 0.88^{\mathrm{b}}$ & $65.78 \pm 3.00^{\mathrm{b}}$ & $8.68 \pm 0.38^{\mathrm{b}}$ \\
50 & $22.53 \pm 0.66^{\mathrm{c}}$ & $42.37 \pm 3.85^{\mathrm{c}}$ & $5.91 \pm 0.47^{\mathrm{c}}$ \\
30 & $13.31 \pm 1.58^{\mathrm{d}}$ & $30.26 \pm 3.66^{\mathrm{d}}$ & $5.00 \pm 0.38^{\mathrm{de}}$ \\
& & & \\
90 & $7.69 \pm 0.15^{\mathrm{f}}$ & $48.96 \pm 2.17^{\mathrm{cd}}$ & $5.54 \pm 0.21^{\mathrm{cd}}$ \\
70 & $7.74 \pm 0.10^{\mathrm{f}}$ & $49.82 \pm 0.93^{\mathrm{c}}$ & $5.96 \pm 0.50^{\mathrm{c}}$ \\
50 & $7.18 \pm 0.24^{\mathrm{f}}$ & $47.52 \pm 2.27^{\mathrm{cd}}$ & $5.25 \pm 0.25^{\mathrm{d}}$ \\
30 & $5.25 \pm 0.17^{\mathrm{g}}$ & $38.29 \pm 1.14^{\mathrm{cd}}$ & $4.99 \pm 0.29^{\mathrm{de}}$ \\
& & & \\
Acetone & $10.82 \pm 1.80^{\mathrm{de}}$ & $50.93 \pm 1.74^{\mathrm{cd}}$ & $5.71 \pm 0.12^{\mathrm{c}}$ \\
90 & $8.78 \pm 0.11^{\mathrm{ef}}$ & $47.98 \pm 1.28^{\mathrm{cd}}$ & $5.54 \pm 0.14^{\mathrm{cd}}$ \\
70 & $6.71 \pm 0.10^{\mathrm{f}}$ & $39.04 \pm 1.28^{\mathrm{cd}}$ & $5.00 \pm 0.41^{\mathrm{d}}$ \\
50 & $6.20 \pm 0.28^{\mathrm{fg}}$ & $37.97 \pm 2.19^{\mathrm{d}}$ & $4.95 \pm 0.32^{\mathrm{e}}$ \\
30 & & &
\end{tabular}

Different letters mean values statistically different at 95\% confidence level.

amount of phytoestrogens were extracted from $L$. tridentata leaves using methanol, which has the highest polarity compared to the other extracting solvents evaluated.

It is worth mentioning that heating has also played an important role in the recovery of these compounds, particularly when using methanol (data not shown), but did not influence the extraction with ethanol or acetone. Some studies have demonstrated the influence of temperature on the extraction of phytochemicals $[23,24]$. Razmara et al. [25] evaluated the effect of temperature, from 19.8 to $60.8^{\circ} \mathrm{C}$, on the solubility of quercetin in different solvent mixtures (water + methanol and water + ethanol), and concluded that raising the solvent temperature increased the solubility of quercetin.

\subsection{Effect of solvents on total phenols, total flavonoids, and protein contents}

Concentration of total phenols, total flavonoids, and protein in the produced extracts are shown in Table 2. As can be seen, the total phenols content ranged from $68.55 \pm 5.81 \mathrm{mg}$ GAE/g dry wt plant when distilled water was used as extraction solvent, to $487.13 \pm 27.68 \mathrm{mg}$ GAE$/ g$ dry wt plant when using $90 \%$ (v/v) acetone. Although it has been reported that the total phenol contents is increased when the solvent polarity is increased [26], the present finding do not show such a trend concerning the solvent polarity, since acetone-water mixtures were proved to be good solvent systems for the extraction of phenolic compounds from $L$. tridentata leaves. In fact, acetone is commonly used and considered quite efficient for the extraction of phenolic substances [27].

There was also a large variation in the total flavonoids content depending on the extraction solvent used, ranging from $4.49 \pm 0.30$ to $19.29 \pm 0.79 \mathrm{mg}$ QE/g dry wt plant for $30 \%$ and $90 \%$ $(\mathrm{v} / \mathrm{v})$ methanol extracts, respectively. It is known that flavonoids can bind proteins, and that their interaction might influence the antioxidant capacity of an extract [28]. Therefore, the effect of the extraction solvent on the protein content was also examined (Table 2). Protein content ranged from $5.79 \pm 0.69$ to $131.84 \pm 6.23 \mathrm{mg} / \mathrm{g}$ dry wt plant for aqueous and $90 \%(\mathrm{v} / \mathrm{v})$ methanol extracts, respectively. A significant linear correlation $(p<0.05)$ was found $(r=0.8977)$ between total flavonoids and protein contents. These results support the idea that the flavonoids present on the plant extracts might have a high potential to bind proteins, which could mask the antioxidant capacity of the extracts. 
Table 2

Total phenols, flavonoids, and protein contents in Larrea tridentata leaves extracts obtained by using different organic solvents.

\begin{tabular}{llcc}
\hline $\begin{array}{l}\text { Solvent } \\
(\%)\end{array}$ & $\begin{array}{l}\text { Total phenols (mg } \\
\text { GAE/g dry wt plant) }\end{array}$ & $\begin{array}{l}\text { Total flavonoids (mg } \\
\text { QE/g dry wt plant) }\end{array}$ & $\begin{array}{c}\text { Protein (mg/g } \\
\text { dry wt plant) }\end{array}$ \\
\hline $\mathrm{H}_{2} \mathrm{O}$ & $68.55 \pm 5.81^{\mathrm{g}}$ & $6.15 \pm 0.72^{\mathrm{d}}$ & $5.79 \pm 0.69^{\mathrm{i}}$ \\
Methanol & & $19.29 \pm 0.79^{\mathrm{a}}$ & $131.84 \pm 6.23^{\mathrm{a}}$ \\
90 & $263.60 \pm 25.78^{\mathrm{e}}$ & $12.23 \pm 0.54^{\mathrm{b}}$ & $113.88 \pm 2.24^{\mathrm{b}}$ \\
70 & $336.70 \pm 32.61^{\mathrm{c}}$ & $7.95 \pm 0.72^{\mathrm{d}}$ & $57.72 \pm 5.36^{\mathrm{f}}$ \\
50 & $227.85 \pm 8.88^{\mathrm{e}}$ & $4.49 \pm 0.30^{\mathrm{e}}$ & $40.01 \pm 0.87^{\mathrm{h}}$ \\
30 & $216.35 \pm 6.18^{\mathrm{e}}$ & & \\
Ethanol & & $12.09 \pm 1.05^{\mathrm{b}}$ & $77.33 \pm 3.46^{\mathrm{d}}$ \\
90 & $201.98 \pm 9.91^{\mathrm{f}}$ & $12.39 \pm 0.55^{\mathrm{b}}$ & $81.11 \pm 1.50^{\mathrm{d}}$ \\
70 & $237.60 \pm 11.58^{\mathrm{e}}$ & $11.54 \pm 0.54^{\mathrm{bc}}$ & $90.26 \pm 1.64^{\mathrm{c}}$ \\
50 & $334.10 \pm 5.80^{\mathrm{c}}$ & & $47.33 \pm 3.49^{\mathrm{g}}$ \\
30 & $285.35 \pm 8.77^{\mathrm{de}}$ & & \\
Acetone & & $12.87 \pm 1.36^{\mathrm{b}}$ & $92.95 \pm 2.16^{\mathrm{c}}$ \\
90 & $487.13 \pm 27.68^{\mathrm{a}}$ & $9.77 \pm 0.27^{\mathrm{c}}$ & $84.73 \pm 3.04^{\mathrm{cd}}$ \\
70 & $409.20 \pm 35.54^{\mathrm{b}}$ & $8.26 \pm 0.28^{\mathrm{cd}}$ & $67.85 \pm 1.60^{\mathrm{e}}$ \\
50 & $315.60 \pm 21.35^{\mathrm{cd}}$ & $59.69 \pm 1.33^{\text {ef }}$ \\
\hline 0 & $311.35 \pm 44.32^{\mathrm{d}}$ & & \\
\hline
\end{tabular}

Different letters mean values statistically different at 95\% confidence level.

\subsection{Antioxidant potential of $L$. tridentata extracts}

Two different techniques based on fundamentally different approaches were used to determine the antioxidant potential of the plant extracts, including 1,1-diphenyl-2-picrylhydrazyl (DPPH) radical scavenging and ferric reducing antioxidant power (FRAP), which are highly sensitive methods with reproducible results. All the produced extracts showed antioxidant potential with similar results for DPPH radical scavenging activity (Table 3 ). Nevertheless, different behavior was observed for FRAP results where extracts obtained using $70 \%$ and $90 \%(\mathrm{v} / \mathrm{v})$ methanol had significantly higher $(p<0.05)$ values $(2.55 \pm 0.09$ and $2.73 \pm 0.11 \mathrm{mM} \mathrm{FE}(\mathrm{II}) / \mathrm{g}$ dry wt plant, respectively) than the remaining ones. Several studies have examined the type of linear correlation between antioxidant activities and phenolic contents in whole plant extracts, fruits, vegetables, and beverages $[29,30]$. Despite the considerable number of literature data reporting significant linear correlations, antioxidant activity might not always correlate with phenolic contents [31,32]. In the present study, FRAP results presented good correlation with the levels of NDGA and quercetin ( $r=0.71$ and 0.88 , respectively), and in particular with kaempferol $(r=0.91)$. However, total phenols content was poorly correlated with FRAP $(r=0.60)$. Such

Table 3

Effect of different organic solvents on antioxidant capacity of Larrea tridentata leaves extracts.

\begin{tabular}{lll}
\hline Solvent (\%) & DPPH inhibition (\%) & FRAP $(\mathrm{mM}$ FE(II)/g dry wt plant $)$ \\
\hline $\mathrm{H}_{2} \mathrm{O}$ & $93.20 \pm 0.40^{\mathrm{e}}$ & $0.77 \pm 0.02^{\mathrm{g}}$ \\
Methanol & & \\
90 & $94.81 \pm 0.33^{\mathrm{ab}}$ & $2.73 \pm 0.11^{\mathrm{a}}$ \\
70 & $94.06 \pm 0.43^{\mathrm{c}}$ & $2.55 \pm 0.09^{\mathrm{a}}$ \\
50 & $94.52 \pm 0.12^{\mathrm{b}}$ & $1.92 \pm 0.18^{\mathrm{d}}$ \\
30 & $94.19 \pm 0.33^{\mathrm{c}}$ & $1.43 \pm 0.02^{\mathrm{f}}$ \\
Ethanol & & \\
90 & $94.97 \pm 0.22^{\mathrm{a}}$ & $1.52 \pm 0.12^{\mathrm{f}}$ \\
70 & $94.28 \pm 0.26^{\mathrm{b}}$ & $1.90 \pm 0.08^{\mathrm{d}}$ \\
50 & $93.71 \pm 0.21^{\mathrm{de}}$ & $2.13 \pm 0.06^{\mathrm{bc}}$ \\
30 & $94.22 \pm 0.20^{\mathrm{c}}$ & $1.74 \pm 0.06^{\mathrm{e}}$ \\
& & \\
Acetone & & $1.89 \pm 0.22^{\mathrm{d}}$ \\
70 & $95.08 \pm 0.17^{\mathrm{a}}$ & $2.16 \pm 0.05^{\mathrm{b}}$ \\
50 & $94.28 \pm 0.24^{\mathrm{b}}$ & $1.81 \pm 0.05^{\mathrm{de}}$ \\
30 & $94.28 \pm 0.33^{\mathrm{bc}}$ & $1.96 \pm 0.06^{\mathrm{cd}}$
\end{tabular}

Different letters mean values statistically different at 95\% confidence level. results indicate that the antioxidant potential of the plant extract might be related to the presence of specific bioactive compounds, as well as by their interaction.

Hidalgo et al. [19] evaluated flavonoid-flavonoid interactions and their effect on the antioxidant capacity by DPPH and FRAP methods. Among several flavonoids, the interaction between kaempferol and quercetin was studied, being concluded that when these compounds were paired an increase in antioxidant activity of about $20 \%$ was achieved compared with their individual theoretical values. According to these authors, the antioxidant potential of a compound is closely related to its structural characteristics, the nature of the radical and its specific reaction mechanism; which can be influenced by the presence of glycosidic moieties, the number and position of hydroxyl and methoxy groups, and the reactions that promote structural changes. Thus, the high antioxidant potential of the extracts obtained using $90 \%(\mathrm{v} / \mathrm{v})$ methanol could be explained by the high concentrations of kaempferol and quercetin and due to their interaction. On the other hand, a significant correlation $(p<0.05)$ was observed between FRAP and the protein content, showing that the known interaction between flavonoids and proteins did not affect the antioxidant capacity of the extracts.

\section{Conclusion}

In brief, extraction with $90 \%(\mathrm{v} / \mathrm{v})$ methanol can be considered as an efficient way to recover phytoestrogens (NDGA, kaempferol, and quercetin) from $L$. tridentata leaves. The extract obtained under this condition is also a valuable source of natural products with antioxidant capacity, and might find a number of industrial applications, particularly in the food and medicinal fields. However, because of the toxicity of methanol, serious issues are pointed out when the purpose of the compounds extracted with this solvent is the application in food and pharmaceutical industries. In order to overcome this problem, the next step of our research work will be focused on finding other less or non-toxic solvents for the extraction of these bioactive compounds, able to promote high extraction results as methanol, or even using bioprocesses such as the solid-state fermentation that do not require the use of any organic solvent. The application of methanol in the present study was useful to establish the maximum amount of phenolic compounds present in $L$. tridentata leaves, as well as to evaluate the antioxidant potential of the obtained extracts. This extraction solvent is one of the most commonly used extraction solvents due to its high polarity, being also recognized for its efficiency to extract phenolic compounds from plant materials.

\section{Acknowledgement}

The authors gratefully acknowledge FCT (Contract/Grant Nos: SFRH/BD/40439/2007 and SFRH/BPD/38212/2007) for financial support of this work.

\section{References}

[1] T. Cornwell, W. Cohick, I. Raskin, Dietary phytoestrogens and health, Phytochemistry 65 (2004) 995-1016.

[2] I.Y. Kim, B.C. Kim, D.H. Seong, D.K. Lee, J.M. Seo, Y.J. Hong, H.T. Kim, R.A. Morton, S.J. Kim, Raloxifene, a mixed estrogen agonist/antagonist, induces apoptosis in androgen-independent human prostate cancer cell lines, Cancer Res. 62 (2002) 5365-5369.

[3] M.S. Steiner, C.R. Pound, I.I.A. Phase, Clinical trial to test the efficacy and safety of Toremifene in men with high-grade prostatic intraepithelial neoplasia, Clin. Prostate Cancer 2 (2003) 24-31.

[4] I.A. Ross, Medicinal Plants of the World - Chemical Constituents, Traditional and Modern Medicinal Uses, vol. 3, Humana Press, New Jersey, 2005.

[5] V. Navarro, M.L. Villarreal, G. Rojas, X. Lozoy, Antimicrobial evaluation of some plants used in Mexican traditional medicine for the treatment of infectious diseases, J. Ethnopharmacol. 53 (1996) 143-147. 
[6] S. Arteaga, A. Andrade-Cetto, R. Cárdenas, Larrea tridentata (Creosote bush), an abundant plant of Mexican and US-American deserts and its metabolite nordihydroguaiaretic acid, J. Ethnopharmacol. 98 (2005) 231-239.

[7] P.W. Hyder, E.L. Fredrickson, R.E. Estell, M. Tellez, R.P. Gibbens, Distribution and concentration of total phenolics, condensed tannins, and nordihydroguaiaretic acid (NDGA) in creosotebush (Larrea tridentata), Biochem. Sys. Ecol. 30 (2002) 905-912.

[8] J.R. Hwu, M.H. Hsu, R.C. Huang, New nordihydroguaiaretic acid derivates as anti-HIV agents, Bioorg. Med. Chem. Lett. 18 (2008) 1884-1888.

[9] M. Zavodovskaya, M.J. Campbell, B.A. Maddux, L. Shiry, G. Allan, L. Hodges, P. Kushner, J.A. Kerner, J.F. Youngren, I.D. Goldfine, Nordihydroguaiaretic acid (NDGA), an inhibitor of the HER2 and IGF-1 receptor tyrosine kinases, blocks the growth of HER2-overexpressing human breast cancer cells, J. Cell. Biochem. 103 (2008) 624-635.

[10] Y. Nakamura, C.-C. Chang, T. Mori, K. Sato, K. Ohtsuki, B.L. Upham, J.E Trosko, Augmentation of differentiation and gap junction function by kaempferol in partially differentiated colon cancer cells, Carcinogenesis 26 (2005) 665-671.

[11] J.E. Brown, H. Khodr, R.C. Hider, C.A. Rice-Evans, Structural-dependence of flavonoid interactions with copper ions: Implications for their antioxidant properties, Biochem. J. 330 (1998) 1173-1178.

[12] A.W. Boots, G.R.M.M. Haenen, A. Bast, Health effects of quercetin: From antioxidant to nutraceutical, Eur. J. Pharmacol. 585 (2008) 325-337.

[13] D. Labbé, M. Provençal, S. Lamy, D. Boivin, D. Gingras, R. Béliveau, The flavonols quercetin, kaempferol, and myricetin inhibit hepatocyte growth factor-induced medulloblastoma cell migration, J. Nutr. 139 (2009) 646652.

[14] Y. Uda, K.R. Price, G. Williamson, M.J. Rhodes, Induction of the antiocarcinogenic marker enzyme, quinone reductase, in murine hepatome cells in vitro by flavonoids, Cancer Lett. 120 (1997) 213-216.

[15] X. Tang, X. Zhu, S. Liu, R.C. Nicholson, X. Ni, Phytoestrogens induce differential estrogen receptor b-mediated responses in transfected MG-63 cells, Endocr. 34 (2008) 29-35.

[16] G.O. de Melo, D.C. Malvar, F.A. Vanderlinde, F.F. Rocha, P.A. Pires, E.A. Costa, L.G. Matos, C.R. Kaiser, S.S. Costa, Antinociceptive and anti-inflammatory kaempferol glycosides from Sedum dendroideum, J. Ethnopharmacol. 124 (2009) 228-232.

[17] S.I. Mussatto, L.F. Ballesteros, S. Martins, J.A. Teixeira, Extraction of antioxidant phenolic compounds from spent coffee grounds, Sep. Purif. Technol. 83 (2011) 173-179.

[18] R. Chirinos, H. Rogez, D. Campos, R. Pedreschi, Y. Larondelle, Optimization of extraction conditions of antioxidant phenolic compounds from mashua (Tropaeolum tuberosum Ruíz E Pavón) tubers, Sep. Purif. Technol. 55 (2007) 217-225.
[19] M. Hidalgo, C. Sánchez-Moreno, S. Pascual-Teresa, Flavonoid-flavonoid interaction and its effect on their antioxidant activity, Food Chem. 121 (2010) 691-696.

[20] L. Wang, C.L. Weller, Recent advances in extraction of nutraceuticals from plants, Trends Food Sci. Technol. 17 (2006) 300-312.

[21] S. Martins, C.N. Aguilar, I. Garza-Rodriguez, S.I. Mussatto, J.A. Teixeira, Kinetic study of nordihydroguaiaretic acid recovery from Larrea tridentata by microwaveassisted extraction, J. Chem. Technol. Biotechnol. 85 (2010) 1142-1147.

[22] F. Lin, M.M. Giusti, Effects of solvent polarity and acidity on the extraction efficiency of isoflavones from soybeans (Glycine max), J. Agric. Food. Chem. 53 (2005) 3795-3800.

[23] M. Bimakr, R.A. Rahman, F.S. Taip, L.T. Chuan, A. Ganjloo, J. Selamat, A. Hamid, Supercritical carbon dioxide $\left(\mathrm{SC}-\mathrm{CO}_{2}\right)$ extraction of bioactive flavonoid compounds from spearmint (Mentha Spicata L.) leaves, Eur. J. Sci. Res. 33 (2009) 679-690.

[24] E. Karacabey, G. Mazza, L. Bayindirli, N. Artik, Extraction of bioactive compounds from milled grape canes (Vitis vinifera) using pressurized lowpolarity water extractor, Food Bioprocess Technol. (2009), doi:10.1007/ s11947-009-0286-8.

[25] R.S. Razmara, A. Daneshfar, R. Sahraei, Solubility of quercetin in water + methanol and water + ethanol from (292.8 to 333.8$) \mathrm{K}$, J. Chem. Eng. Data 55 (2010) 3934-3936.

[26] Z. Tunalier, M. Kosar, E. Kupeli, I. Calis, K.H.C. Baser, Antioxidant, antiinflammatory, anti-nociceptive activities and composition of Lythrum salicaria L. extracts, J. Ethnopharmacol. 110 (2007) 539-547.

[27] G.A. Akowuah, Z. Ismail, I. Norhayati, A. Sadikun, The effects of different extraction solvents of varying polarities on polyphenols of Orthosiphon stamineus and evaluation of the free radical-scavenging activity, Food Chem. 93 (2005) 311-317.

[28] M.J.T.J. Arts, G.R.M.M. Haenen, L.C. Wilms, S.A.J.N. Beetstra, C.G.M. Heijnen, H.P. Voss, A. Bast, Interactions between flavonoids and proteins: Effect on the total antioxidant capacity, J. Agric. Food. Chem. 50 (2002) 1184-1187.

[29] M. Alothman, R. Bhat, A.A. Karim, Antioxidant capacity and phenolic content of selected tropical fruits from Malaysia, extracted with different solvents, Food Chem. 115 (2009) 785-788.

[30] K. Tawaha, F.Q. Alali, M. Gharaibeh, M. Mohammad, T. El-Elimat, Antioxidant activity and total phenolic content of selected Jordanian plant species, Food Chem. 104 (2007) 1372-1378.

[31] I.M. Heinonen, A.S. Meyer, E.N. Frankel, Antioxidant activity of berry phenolics on human low-density lipoprotein and liposome oxidation, J. Agric. Food. Chem. 46 (1998) 4107-4112.

[32] M.P. Kahkonen, A.I. Hopia, H.J. Vuorela, J.-P. Pauha, K. Pihlaja, T.S. Kujala, M. Heinonen, Antioxidant activity of plant extracts containing phenolic compounds, J. Agric. Food. Chem. 47 (1999) 3954-3962. 